\title{
Morphological and molecular identification of fungi associated with south African apple core rot
}

Elaine Basson, 1

Julia C. Meitz-Hopkins, $1 \square$

Phone +27 (0)21 8089177

Email juliam@sun.ac.za

Cheryl L. Lennox, 1

${ }^{1}$ Fruit and Pathology Research Programme, Department of Plant Pathology, Stellenbosch University, Private Bag X1, Matieland, 7602 South Africa

\begin{abstract}
Core rot is a major contributor to postharvest losses in apples worldwide. Pathogens most commonly associated with the disease are Alternaria spp. and Penicillium spp. Although both genera show specific morphological characteristics, they can be difficult to identify to species level. In this study, Alternaria spp. (49) and Penicillium spp. isolates (97), associated with pre- and post-harvest apple core rot-symptoms and isolates from potential inoculum sources were identified using molecular methods. Initially, dry core rot causing Alternaria spp. were identified morphologically in an average of $70 \%$ of infected fruit pre-harvest and $32 \%$ postharvest. Furthermore, $78 \%$ of mouldy core rot causing pathogens were identified as Alternaria spp. preharvest and $40 \%$ postharvest. Wet core rot was associated with Penicillium spp. in $64 \%$ of cases preharvest and $36 \%$ postharvest. Species identity of a selection of samples was confirmed using the endopolygalacturonase (endo-PG) gene, the ITS region, and the anonymous genomic regions (OPA1-3, 2-1), which resulted in the identification of A. alternata, A. arborescens, A. dumosa, A. eureka and A. tenuissima. Penicillium species were identified through ITS sequencing and partial beta-tubulin polymerase chain reaction - random fragment length polymorphisms (PCR-RFLP) for the samples collected from wet core rot symptoms. Phylogenetic analyses separated the Alternaria spp. into five clades, including three separate clades for A. alternata, A. tenuissima and A. arborescens, respectively. This is the first report of A. eureka and P. polonicum as potential core rot pathogens. Phylogenetic analysis identified Penicillium ramulosum and $P$. expansum as the most commonly occurring species associated with WCR symptoms.
\end{abstract}

\section{Keywords}

Alternaria- and Penicillium species identification

Multi-gene phylogeny

Postharvest pathogens

Electronic supplementary material

The online version of this article ( https://doi.org/10.1007/s10658-018-1601-x ) contains supplementary material, which is available to authorized users.

\section{Introduction}

AQ1

Core rot, caused by various pathogenic fungi including several Alternaria and Penicillium species, is a major post-harvest disease of apples world-wide. Control of postharvest pathogens is complicated by the fact that infection might occur at any time from bloom or during fruit development depending on the causal pathogen. Fungicides are usually registered for specific disease causing pathogens, since they have varying control efficacy on different pathogen species. Therefore species identification of the causal organisms of the disease is required. Another complication is that fungal spores, such as Alternaria spp., could be carried into the apple cavity by mites (Tarsonemus sp.). Particularly susceptible to Tarsonemus mite-vectored infections would be the open calyx varieties such as Red Delicious (van der Walt et al. 2011). Therefore fungicide application during bloom alone, might not be effective to control all core rot pathogens. Currently no fungicides are applied to control Alternaria sp. in South Africa, although other fungicide applications to prevent apple scab infection, such as difenoconazole are thought to also inhibit $A$. alternata (Reuveni and Sheglov 2002 ; Reuveni and Prusky 2007). The apple variety Starking (sport of Red Delicious) was found to be particularly susceptible to core rot, with over $20 \%$ decay caused in single consignments leading to rejection at the export destination (pers. com. Dr. Cheryl Lennox). About $12 \%$ of the total apple areas planted in South Africa in 2016 was either the apple variety Topred or Starking, which corresponds to 2947 ha of orchards (Hortgro Statistics 2016). Currently identification of fungal species that cause core rot is labour intensive and requires trained personnel and laboratory facilities. Molecular methods are promising tools for species identification, which would enable targeted control strategies. A quick, reliable identification method for fungal pathogens, would also allow monitoring of quarantine pathogens. South Africa has quarantine requirements against Alternaria mali Roberts, as this species does not occur in the country. Screening of quarantine organisms from imported plant material can reduce the risk of quarantine organisms causing major losses if not contained.

Core rot includes three symptoms, namely mouldy core (MC), dry core rot (DCR) and wet core rot (WCR) (Carpenter 1942). Core rot symptoms are generally restricted to inside and around the core cavity of the fruit and external symptoms are rare (Combrink and Ginsburg 1973; Reuveni et al. 2003, 2007). Mouldy core symptoms are restricted to the core cavity of the apple, whereas those of DCR infect the tissue surrounding the core cavity forming a dry, corky lesion (Carpenter 1942). Fungi associated with WCR move rapidly through the tissue causing a soft, wet rot. Niem et al. (2007) established that core rot causal organisms infect during blossom, especially infecting apple cultivars with an open calyx end (Miller 1959). Shtienberg (2012), on the other hand, found a correlation between fruit cultivar size and Alternaria alternata (Fr.) Keissler infection risk.

Based on morphological characteristics, fungi previously associated with core rot were identified as Alternaria Nees, Aspergillus P. Micheli ex Link, Botryosphaeria Ces. and De Not., Botrytis P. Micheli ex Pers., Candida Cif. and Redaelli, Cladosporium Link, Colletotrichum Corda and Deutschl., Coniothyrium Corda, Epicoccum Link, Fusarium Link, Gloeosporium Desm. and Mont., Penicillium Link, Pestalotia De Not., Phoma Sacc., Trichoderma Pers., Rhizopus Ehrenb., Pleospora Rabenh. ex Ces. and De Not., Spencermartinsia Phillips, Alves and Crous, Stemphylium Wallr., Trichothecium Link, Ulocladium Preuss and others (Taylor 1955; Ellis and Barrat 1983 ; Combrink et al. 1985; Spotts et al. 1988; Spotts 1990; Van der Walt et al. 2010; Gao et al. 2013). The most prevalent fungi associated with DCR and MC are Alternaria spp. while Penicillium spp. and sometimes Fusarium spp. are associated with WCR (Combrink and Ginsburg 1973; Combrink et al. 1985; Spotts 1990; Wenneker et al. 2016). As morphological identification of core rot fungi to species level is not always possible, since some species have very similar morphology (i.e. cryptic species), molecular characterisation is frequently used. Some fungi can be identified to species level using a single genetic locus such as the beta-tubulin gene for Penicillium spp. (Seifert et al. 2007), whereas other species can only be distinguished using multiple gene regions such as A. alternata and A. tenuissima Nees and T. Nees: Fr. Wiltshire (Peever et al. 2004, 2005).

The four Alternaria species most frequently associated with core rot in South Africa are A. alternata, A. tenuissima, A. arborescens E.G. Simmons and A. infectoria E.G. Simmons (Kang et al. 2002; Serdani et al. 2002). Only A. infectoria could be distinguished from the other three species using the internal transcribed spacer (ITS) as there is a lack of polymorphism in the ITS region (de Hoog and Horré 2002; Berbee et al. 2003; Andersen et al. 2009). Alternative genetic loci have been used to identify the smallspored species of Alternaria with varying levels of success. These gene regions include glyceraldehyde-3-phosphate dehydrogenase (gpd), translocation elongation factor $1 \alpha$ (tef- $1 \alpha$ ), endo-PG, mitochondrial small and large ribosomal subunits (mtSSU and mtLSU), beta-tubulin and anonymous genomic regions OPA1-3, OPA2-1 and OPA10-2 (Kusaba and Tsuge 1995; Pryor and Gilbertson 2000; Pryor and Michailides 2002; de Hoog and Horré 2002; Peever et al. 2002, 2004, 2005; Pryor and Bigelow 2003; Hong et al. 2005; Pavón et al. 2010). These sequences could identify A. arborescens and other Alternaria species but $A$. alternata and $A$. tenuissima could not be distinguished (Pryor and Michailides 2002). 
Penicillium species isolated from apple WCR worldwide include P. aurantiogriseum Dierckx, P. brevicompactum Dierckx, P. commune Thom, P. crustosum Thom, P. expansum Link, and P. solitum Westling (Amiri and Bompeix 2005). Similarly, P. expansum has been reported as the causal organism for WCR in South Africa (Combrink and Ginsburg 1973; van der Walt et al. 2010). Infection was thought to occur during the diphenylamine (DPA)-emulsion treatment of pome fruit against superficial scald in the pack house (Combrink et al. 1985, 1987; Spotts et al. 1988). Penicillium spores could be washed into the open calyx through the fungi-contaminated DPA-emulsion as DPA lowers the surface tension of the suspension and allows the water to move through the open calyx (Combrink and Ginsburg 1973). Currently DPA is being phased out and replaced with 1-methylcyclopropene (1-MCP), a gaseous ethylene inhibitor (Kim and Xiao 2008) which does not protect against fungi and has been reported to increase the decay incidence of $P$. expansum post-harvest (Janisiewicz et al. 2003; Leverentz et al. 2003; Kim and Xiao 2008). Wet core rot infection has been suggested to take place in the orchard prior to harvest (de Kock et al. 1991; Van der Walt et al. 2010). Although detailed studies on inoculum sources have not been conducted previously.

Several other species of the genus Penicillium, have been identified to cause WCR. Sanderson and Spotts (1995) identified the species, such as P. solitum Westling, collected from their symptomatic fruit using the colony colour and morphology of the isolates. Penicillium roquefortii Thom has been found in field bins and from wet core rot and decay lesions on apples and pears post-harvest (Sanderson and Spotts 1995; Spotts et al. 1988). Two other Penicillium species, namely, P. expansum and P. funiculosum Thom were reported to cause WCR in South Africa (Combrink and Ginsburg 1973; Combrink et al. 1985; de Kock et al. 1991; Serdani et al. 1998). Van der Walt et al. (2010) identified the species of Penicillium found in three apple production areas of South Africa that caused pre-harvest WCR, and characterised the virulence and pathogenicity of these isolates. The species identified were P. ramulosum prov. Nom., P. expansum, Penicillium sp. (aff. P. dendriticum Pitt), P. glabrum (Wehmer) Westling, Penicillium sp. (aff. P. cecidicola Seifert, Hoekstra and Frisvad) and P. chermesinum Biourge.

The following gene regions have been used to identify Penicillium species: ITS, cytochrome c oxidase 1 (CO1) gene, and the beta-tubulin gene (Lobuglio et al. 1993, 1994; Skouboe et al. 1999; Seifert et al. 2007). Van der Walt et al. (2010) used the beta-tubulin PCR-RFLP technique with restriction enzymes HaeIII and RsaI to distinguish between Penicillium species isolated from core rot symptoms.

The objective of this study was to identify the Alternaria and Penicillium species sampled from symptomatic core rot fruit and inoculum sources (air, mummies and mites), using molecular methods.

\section{Materials and methods}

\section{Core rot fungal isolations and inoculum sources}

In 2009 and 2010, core rot infected apples $(N=291)$ were collected from two 'Starking' orchards ("orchard B and C") in the Koue Bokkeveld pre- and postharvest, Western Cape and fungi isolated, single spored and identified. Monospore cultures of Alternaria spp. $(N=49)$ and Penicillium spp. isolates ( $N=97)$ were collected from fruit of orchard B and air samples collected from orchards B and C. In addition, single spored isolates collected from other inoculum sources (mummies and mites) from orchard B during the bloom period for both seasons were included (Supplementary Table 1).

\section{Core rot inoculum source and fungal isolation}

Air samples were collected during bloom at ten sites per orchard at 1 and 3 min intervals, with each site replicated three times. A portable air sampler (Burkard Manufacturing Co Ltd., Hertfordshire, UK, patent No. 8819423.8) was used to collect airborne conidia onto potato dextrose agar (PDA) plates. The plates were incubated for seven days at $21^{\circ} \mathrm{C}$ room temperature, and fungal colonies sub-cultured onto PDA before being identified using molecular methods.

Mummified fruit, overwintered from the previous season, were collected from the same orchards where the air samples were taken in 2009 and 2010 . From each orchard, 10 mummies were collected from 10 trees in accordance with Hong et al. (2000). Mummies were transported to the laboratory in brown paper bags sealed in plastic bags. Mites, retrieved from mummies with a thin needle, were placed in $1 \mathrm{ml}$ sterile distilled water (SDW) in a 2-ml Eppendorf tube. Glass beads were placed in the SDW solution containing the mites and vortexed for $1 \mathrm{~min}$. One hundred microliter of the mite - washing water was plated out onto each of three PDA plates. Plates were incubated at room temperature for 7 days after which fungal colonies were identified using molecular methods.

\section{Isolation of fungi associated with core rot from orchard fruit pre-harvest}

In 2009 and 2010 non-symptomatic fruit were collected from the orchard floor in March, two weeks (14 d) before harvest. Commercial farms with a history of core rot were selected in the Witzenberg Valley (near Ceres). In 2009, 200 fruit and in 2010, 800 fruit were collected pre harvest (20 fruit per tree). In the laboratory, the surface sterilised ( $70 \%$ ethanol for $30 \mathrm{~s}$ ) fruit was cut in half and isolations were made from the edge of core rot lesions, which were classified as either dry core, mouldy core or wet core rot.

\section{Isolation of fungi associated with core rot on fruit at harvest}

Ten replicates of 100 fruit were harvested in April 2009 and 2010, and stored under controlled atmosphere for up to seven months. Post-harvest isolations were made as described above from symptomatic fruit $(N=126$ in $2009 ; N=176$ in 2010).

\section{Molecular identification}

\section{DNA extraction}

The Alternaria and Penicillium isolates were grown on PDA at $21^{\circ} \mathrm{C}$ for 4 to 7 days. DNA was extracted from resulting mycelial growth using the UltraClean ${ }^{\circledR}$ Microbial DNA Isolation kit (MoBio Laboratories, Inc., Carlsbad, CA, USA) following the manufacturer's instructions.

\section{PCR-RFLP of pre- and post-harvest wet core rot Penicillium species}

Genomic DNA was extracted from 124 single-spored Penicillium isolates using a modified method by Lee and Taylor (1990). The beta-tubulin PCR-RFLP group of each isolate was determined by PCR amplification of a partial region of the beta-tubulin gene using primers Bt2a (5'-GGTAACCAAATCGGTGCTGCTTTC-3') (Glass and Donaldson 1995) and PentubR (5'-GACGGACGACATCGAGAACCTG-3') (Van der Walt et al. 2010). The PCR reaction consisted of $0.2 \mu$ M of each primer, 0.2 mM of each dNTP, $1 \times$ PCR buffer, 0.5 U BIOTAQ DNA polymerase, $0.2 \mathrm{mg}$ bovine serum albumin (BSA) Fraction V, $2 \mu \mathrm{DNA}$ and $3 \mathrm{mM} \mathrm{MgCl}{ }_{2}$ in a final volume of $40 \mu \mathrm{l}$. Amplifications were conducted in a 2720 Applied Biosystems thermocycler, starting with an initial denaturation cycle of 5 min at $94{ }^{\circ} \mathrm{C}$, followed by 40 cycles of $45 \mathrm{~s}$ at $94{ }^{\circ} \mathrm{C}, 45 \mathrm{~s}$ at $55^{\circ} \mathrm{C}$ and $60 \mathrm{~s}$ at $72{ }^{\circ} \mathrm{C}$, and a final extension cycle of $7 \mathrm{~min}$ at $72{ }^{\circ} \mathrm{C}$.

Successfully amplified PCR products were digested using the restriction enzymes HaeIII and RsaI (Fermentas Inc., Glen Burnie, MD, USA). The HaeIII digest reaction consisted of $1 \times$ enzyme buffer, $15 \mathrm{U} / \mu \mathrm{l}$ HaeIII and $10 \mu \mathrm{l}$ PCR product in a total volume of $20 \mu \mathrm{l}$. The RsaI digestion reaction consisted of $1 \times$ enzyme buffer, $5 \mathrm{U} / \mu 1$ RsaI and $10 \mu \mathrm{l}$ PCR product in a total volume of $20 \mu \mathrm{l}$. Digests were incubated overnight at $37^{\circ} \mathrm{C}$, and $15 \mu$ of the restriction digest products were separated along with a 50 bp DNA standard on a $3 \%$ agarose gel (Seakem ${ }^{\circledR}$, Lonza, Rockland, ME USA) containing $0.001 \%$ of ethidium bromide. Isolates exhibiting the same restriction pattern for both enzymes were classified into the same beta-tubulin PCR-RFLP groups using the Van der Walt et al. (2010) restriction patterns as controls (Figs. 1, 2, 3, and 4).

Fig. 1

Phylogeny of Alternaria species based on the internal transcribed spacer of ribosomal RNA region. The tree presents one of ten equally parsimonious trees of a heuristic search $(\mathrm{TL}=248, \mathrm{CI}=0.734, \mathrm{RI}=0.875, \mathrm{RC}=0.642 ; 91$ parsimony informative characters). The reference sequences for A. alternata, A. arborescens, A. longipes and A. tenuissima grouped together in one clade. The phylogenetic tree was rooted with the reference isolates Pleospora tarda and Paradendryphiella salina. Branch lengths are proportional to the inferred amount of evolutionary change and the scale represents 5.0 nucleotide substitutions per site 


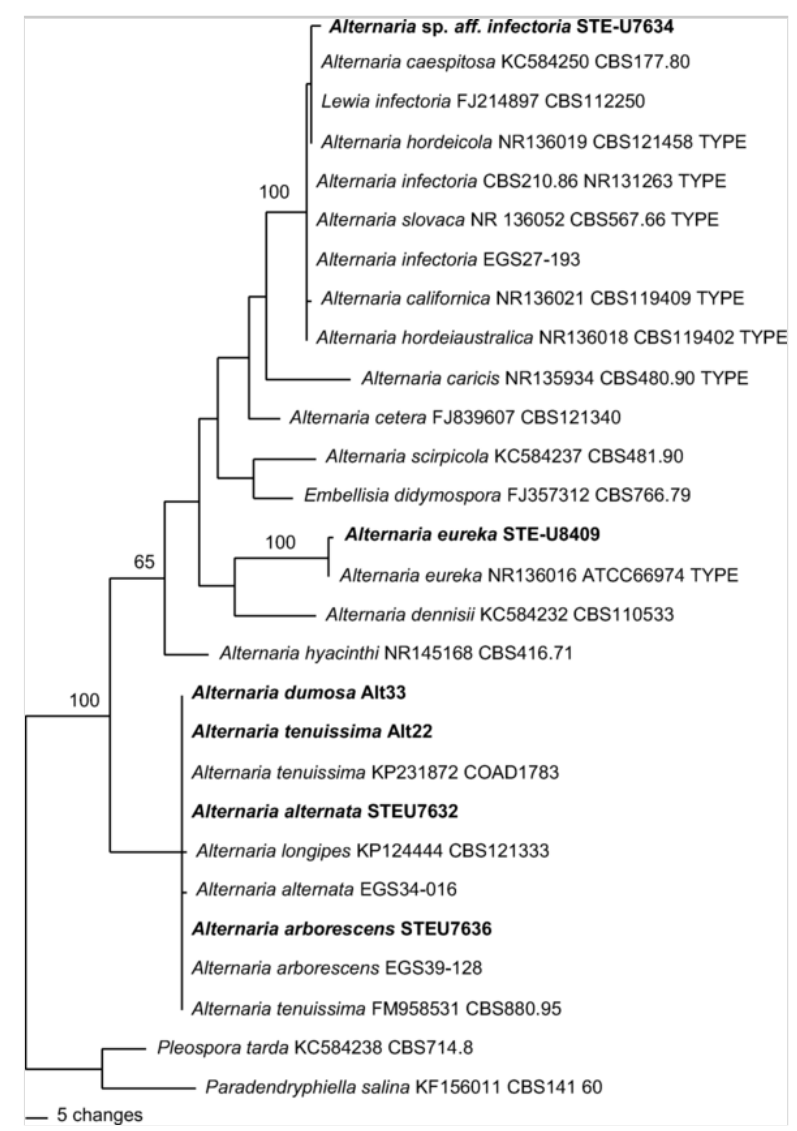

Fig. 2

Phylogeny of Alternaria species sampled from apple and apple orchard air samples based on the combined sequences of the endopolygalacturonase gene (endoPG), OPA1-3 and OPA2-1 regions. The tree presents one of two equally parsimonious trees of a heuristic search. Numbers within the tree represents the bootstrap values followed by probability values in brackets. Bootstrap values lower than $60 \%$ are not shown. Branch lengths are proportional to the inferred amount of evolutionary change and the scale represents 5.0 nucleotide substitutions per site. $\mathrm{TL}=204, \mathrm{CI}=0.760, \mathrm{RI}=0.918$. Reference sequences $(\mathrm{EGS})$ in bold print represent type strains and isolates from citrus as published by Peever et al. (2004 and 2005). Numbers in columns with header (endoPG, OPA1-3, OPA2-1) indicate clade designations of sequences in individual loci's phylogenetic analysis (incongruences between phylogenies are indicated by hatched boxes) 


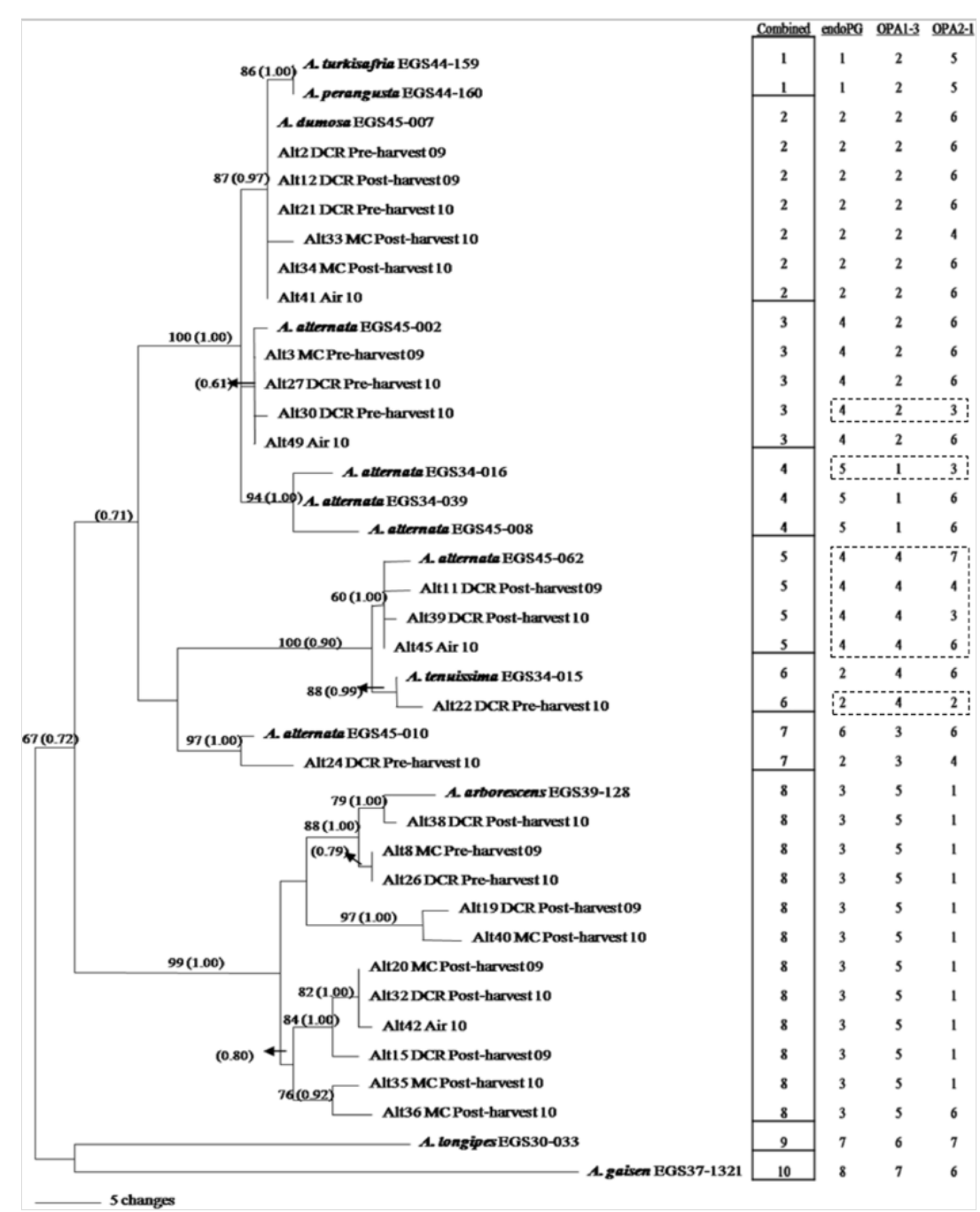

Fig. 3

The phylogenetic tree obtained from one of 830 parsimony analysis trees from the ITS region (including Genbank entries of the same genetic region from Penicillium expansum, P. cecidicola, P. funiculosum, P. dendriticum, P. chermesinum, P. sp. (aff. Dendriticum and cecidicola), P. paneum, P. solitum, P. crustosum, P. brevicompactum, P. novaezeelandiae, P. glabrum, P. rugulosum, P. ramulosum and Clonostachys rogersoniana). The scale bar indicates the number of base changes per 100 nucleotide positions in the parsimony analysis, with parsimony bootstrap values of 1000 replicates indicated above and below the branches respectively. Bootstrap values lower than $60 \%$ are not shown 


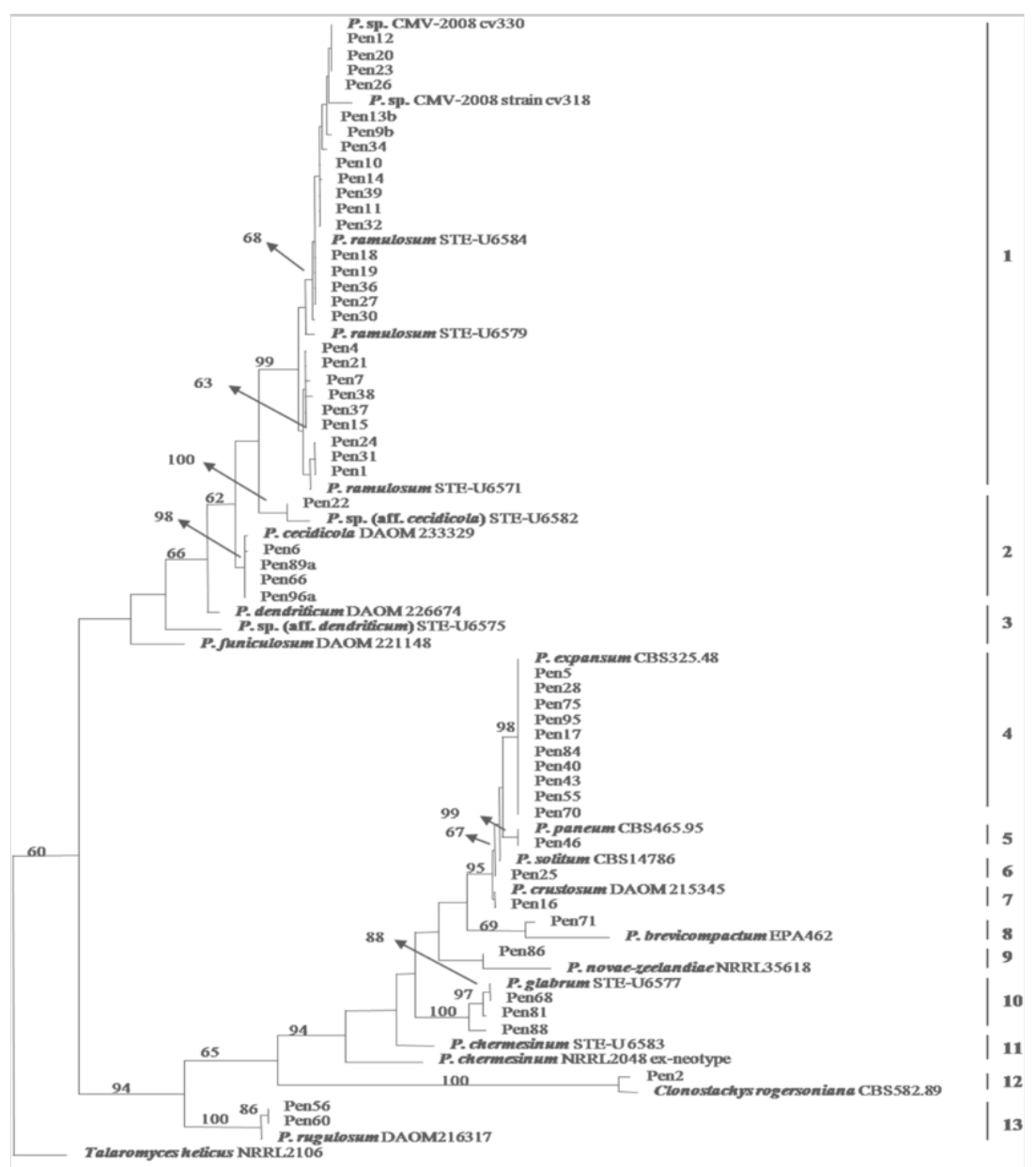

- 5 changes

Fig. 4

The phylogenetic tree obtained from one of 4 parsimony analysis trees from the beta tubulin region, including Genbank entries of the same genetic region from Clonostachys rosea, Penicillium chermesinum, P. crustosum, P. expansum, P. lanosum, P. polonicum, and Talaromyces ramulosus. The scale bar indicates the number of base changes per 100 nucleotide positions in the parsimony analysis, with parsimony bootstrap values of 1000 replicates indicated above and below the branches respectively. Bootstrap values lower than $60 \%$ are not shown. Isolates from the current study in bold

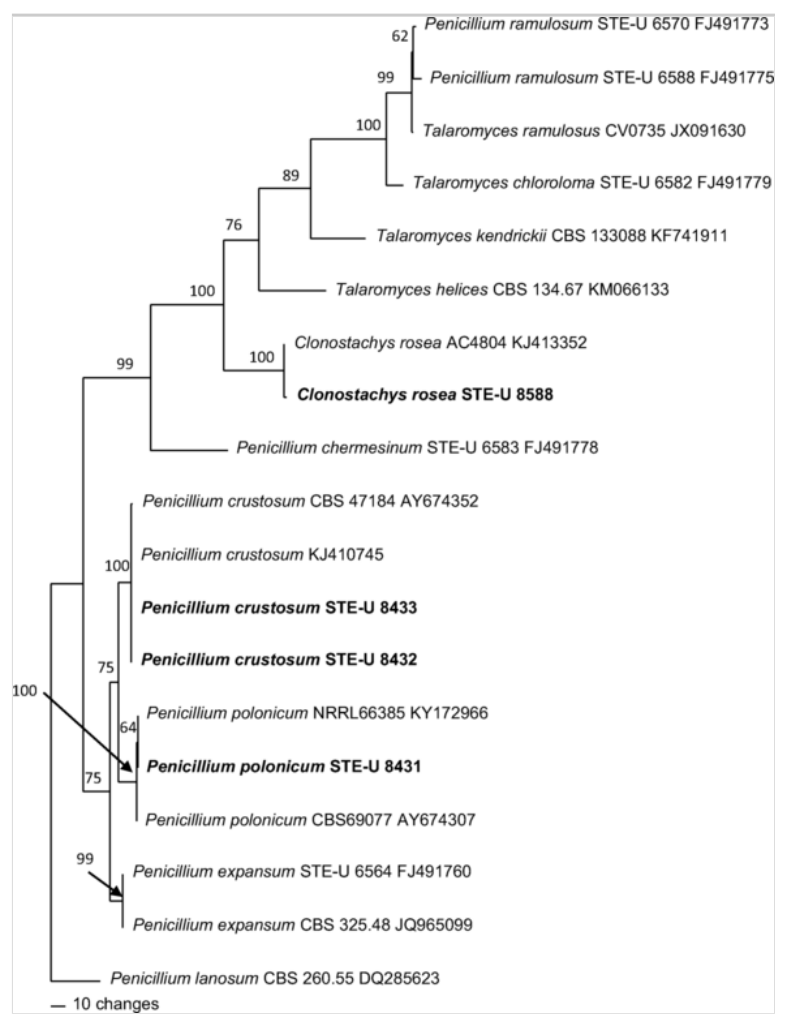

AQ2

PCR amplification and sequencing 
To identify individual Alternaria species, four genetic loci (endoPG, ITS, OPA1-3, OPA2-1) were used for sequence analysis. Samples were amplified in an Applied Biosystems 2720 Thermal cycler. The endoPG gene was amplified using primers PG3 (5'-TACCATGGTTCTTTCCGA-3') and PG2B (5'-

GAGAATTCRCARTCRTCYTGRTT-3') as described in Isshiki et al. (2001) with the following programme: initial denaturation step for 2 min at $95{ }^{\circ} \mathrm{C}, 35$ cycles of 1 min at $95{ }^{\circ} \mathrm{C}, 1 \mathrm{~min}$ at $50{ }^{\circ} \mathrm{C}, 1 \mathrm{~min}$ at $72{ }^{\circ} \mathrm{C}$, and extension for $5 \mathrm{~min}$ at $72{ }^{\circ} \mathrm{C}$. All PCR reactions were performed using a PCR machine (2700 Applied Biosystems) and the reaction mixture contained $1.5 \mathrm{mM} \mathrm{MgCl}_{2}, 1 \times$ reaction buffer, $2.5 \mathrm{mM}$ dNTP, $0.5 \mu \mathrm{M}$ of each primer, $2.5 \mathrm{U}$ Bioline Taq polymerase and $1 \mu$ l of fungal DNA in a final volume of $25 \mu$ l. The Penicillium. ITS region was amplified using the primers V9G (5'-TTACGTCCCTGCCCTTTGTA-3') and Ls266 (5'GCATTCCCAAACAACTCGACTC-3') (de Hoog and van den Ende 1998; White et al. 1990), The ITS programme consisted of an initial denaturation step for 5 min at $94{ }^{\circ} \mathrm{C}, 5 \mathrm{cycles}$ of $30 \mathrm{~s}$ at $94{ }^{\circ} \mathrm{C}$, $40 \mathrm{~s}$ at $55^{\circ} \mathrm{C}$ and $1 \mathrm{~min}$ at $72{ }^{\circ} \mathrm{C}, 5$ cycles of $30 \mathrm{~s}$ at $94{ }^{\circ} \mathrm{C}, 40 \mathrm{~s}$ at $54{ }^{\circ} \mathrm{C}$ and $1 \mathrm{~min}$ at $72{ }^{\circ} \mathrm{C}, 25$ cycles of $30 \mathrm{~s}$ at $94{ }^{\circ} \mathrm{C}, 40 \mathrm{~s}$ at $53{ }^{\circ} \mathrm{C}$ and $1 \mathrm{~min}$ at $72{ }^{\circ} \mathrm{C}$, and extension for 5 min at $72{ }^{\circ} \mathrm{C}$. The ITS PCR reaction contained $1.5 \mathrm{mM} \mathrm{MgCl}_{2}, 0.05 \mathrm{mg}$ DMSO, $1 \times \mathrm{NH}$ buffer, $1 \mathrm{mM}$ dNTP, $10 \mu \mathrm{M}$ of each primer, $5 \mathrm{U}$ Taq polymerase and $1 \mu \mathrm{l}(25 \mathrm{ng}-100 \mathrm{ng})$ of fungal DNA in a final volume of $25 \mu \mathrm{l}$. A partial beta tubulin sequence amplified as described above was sequence analysed using primers Bt2a and PentubR (van der Walt et al. 2010) from a selected number of Penicillium sp. isolates to confirm species identity. After PCR amplification the products were confirmed by separation on a $1 \%$ agarose gel. PCR primers used for the OPA1-3 and OPA2-1 regions were OPA1-3 L (5'-AGGCCCTTCCAATCCAT-3') and OPA1-3Rb (5'-AGCCACATGCTCTGGTTAGC-3'), and OPA21 L (5'-TGCCGAGCTGTCAGATAATTG-3') and OPA2-1R (5'-GCCGAGCTGGTGGAGAGAGT-3'), respectively. As described in Peever et al. (2004) the following programme was used: an initial denaturation step for $1 \mathrm{~min}$ at $94{ }^{\circ} \mathrm{C}, 35$ cycles of $20 \mathrm{~s}$ at $94{ }^{\circ} \mathrm{C}, 20 \mathrm{~s}$ at $56{ }^{\circ} \mathrm{C}, 20 \mathrm{~s}$ at $72{ }^{\circ} \mathrm{C}$, and extension for 5 min at $72{ }^{\circ} \mathrm{C}$. PCR reagents used were $1 \mathrm{x}$ reaction buffer, $0.2 \mathrm{mM}$ of each primer, $200 \mathrm{mM} \mathrm{dNTP}, 2.5 \mathrm{mM} \mathrm{MgCl}{ }_{2}, 25 \mathrm{ng}-100 \mathrm{ng}$ of DNA and 1 unit of Bioline Taq polymerase. Sequencing reactions were conducted using the same primers as for the PCR amplification, using $1 \mu \mathrm{l}$ PCR product in a $10 \mu \mathrm{l}$ reaction, consisting of distilled water, $10 \mu \mathrm{M}$ primer, $1 \times$ sequence mix (BigDye) and $5 \times$ buffer. The sequence programme followed an initial denaturation of $1 \mathrm{~min}$ at $95{ }^{\circ} \mathrm{C}, 30$ cycles of denaturation for $10 \mathrm{~s}$ at $95{ }^{\circ} \mathrm{C}$, and annealing for $5 \mathrm{~s}$ at $50{ }^{\circ} \mathrm{C}$ and 4 min extension at $60^{\circ} \mathrm{C}$. The sequencing product was filtered through a Sephadex filled filter plate and centrifuged at $910 \mathrm{rpm}$. Samples were analysed on an ABI Prism 3700 genetic analyser (Applied Biosystems, Foster City, CA), and forward and reverse sequences were assembled with the programme Geneious Pro 5.3.3 (Biomatters Ltd., Auckland, New Zealand). Representative isolates' sequences and cultures were submitted to Genbank (accession KX868611- KX868653; Supplementary Tables 2 and 3) or to the Stellenbosch University culture collection at the Plant Pathology department (STE-U 7629, STE-U 7630, STE-U7631, STE-U 7632, STE-U 7633, STE-U 7634, STE-U 7635, STE-U 7636, STE-U 7637, STE-U 8409, STE-U 8431-STE-U 8432, STE-U8433, STE-U 8588; Fig. 5).

Fig. 5

Mean lesion diameter of (A) five Alternaria spp. in pathogenicity tests after $10 \mathrm{~d}$ incubation (mean of two trials). Isolates used were STE-U 8409 (A. eureka) STE-U 7632 (A. alternata), STE-U 7634 (A. infectoria) and STE-U7636 (A. arborescens) and (B) one Clonostachys sp. and three Penicillium spp. mean lesion size in pathogenicity test. Isolates used were STE-U 8588 (Clonostachys rosea, PEN05), STE-U 8431 (Penicillium polonicum, PEN06), STE-U 8433 (P. crustosum, PEN16), and STE-U 8432 (P. crustosum, PEN18). Vertical bars denote standard error

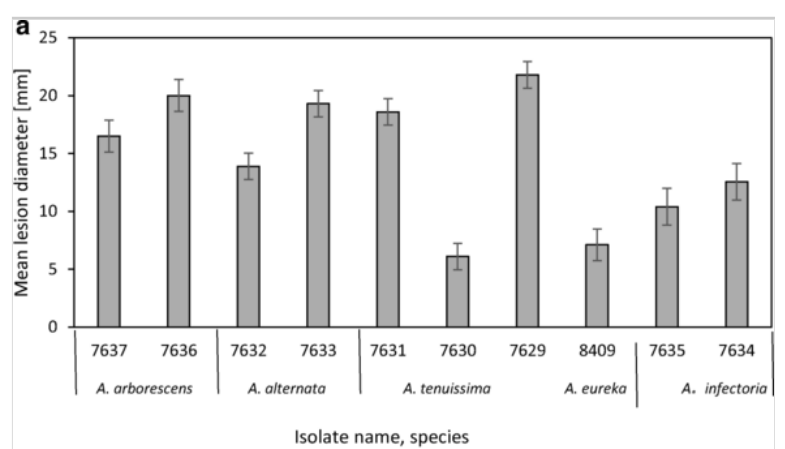

b

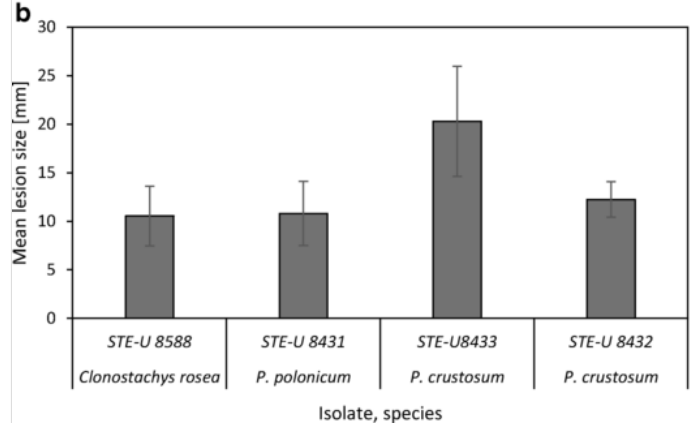

AQ3

Phylogenetic analysis and partition homogeneity test

ITS sequences of Alternaria reference strains and representative isolates from the trials were aligned using the software programme CLUSTAL W (Thompson et al. 1994). Alternaria sequences from the datasets endoPG, OPA1-3 and OPA2-1 were aligned using MAFFT sequence alignment programme version 6 (Katoh and Toh 2008) followed by manual adjustments of the alignments in Sequence Alignment Editor v. 2.0a11 (Rambaut 2002). Maximum parsimony analysis as well as Bayesian analysis was conducted on the Alternaria sequence alignments using PAUP* (Phylogenetic Analysis Using Parsimony) v.4.0b10. The analysis was performed using the heuristic search option with 100 random taxon additions. Tree bisection and reconstruction (TBR) was used as the branch swapping algorithm with the option of saving no more than 10 trees with a score greater or equal to five (Harrison and Langdale 2006). Bootstrap support values were calculated from 1000 heurisitic search replicates and 100 random taxon additions. Bootstrap values below $60 \%$ were not included for each genetic locus' phylogenetic analysis. Other measures calculated for the parsimony analysis include tree length (TL), consistency index (CI), retention index (RI) and rescaled consistency index (RC) values.

Topologies of the resulting phylograms were compared using incongruence length difference (ILD) tests (Farris et al. 1994) to determine the suitability of combining the endoPG, OPA1-3 and OPA2-1 data sets. ILD tests were implemented in PAUP* (referred to as "partition homogeneity tests" in PAUP*) with invariant characters removed and 1000 randomized partitions. Tested data partitions included: (i) endoPG, OPA $1-3$ and OPA $2-1$; (ii) endoPG and OPA1-3, (iii) endoPG and OPA2-1, and (iv) OPA1-3 and OPA2-1. Data partitions were considered significantly different at $P<0.05$ (Swofford 2002). Phylogenetic trees were uploaded to TreeBASE (submission ID 19918). Genbank reference sequences used are listed in Supplementary Tables 2 and 3.

\section{Pathogenicity tests}

Inoculum was prepared as described in Serdani et al. (2002) by incubating sterile toothpicks ( $32 \mathrm{~mm} \times 2 \mathrm{~mm}$ ) and autoclaved 5 times, lastly in potato dextrose broth (PDB) with mycelial plugs of Alternaria spp. or Penicillium spp. isolates growing on PDA for two weeks at $21^{\circ} \mathrm{C}$ under high relative humidity ( 85 to $90 \%$ ). Ten 'Starking' apples were surface sterilised using $70 \%$ ethanol and wounded using the inoculated toothpicks near the calyx end (about $2 \mathrm{~cm}$ away), or a sterile toothpick as a non-inoculated control. Fruit was incubated at $23^{\circ} \mathrm{C}$ in humidity chambers for $5 \mathrm{~d}$ (for Penicillium spp.) and $10 \mathrm{~d}$ (for Alternaria spp.). Re-isolation from the edge of the lesion was done to confirm pathogenicity of the tested isolates, and fulfil Koch's postulates. Analysis of variance of pathogenicity data was conducted using Statistica v. 13.6. Fisher's least significant difference was used to determine significant differences between isolates. 
Results

Genera identified from the symptomatic core rot fruit and inoculum sources included Alternaria, Aspergillus, Botrytis, Cladosporium, Epicoccum, Fusarium, Gloeosporium, Penicillium, Stemphylium, Trichoderma, Ulocladium, and Verticillium (data not shown). Fungal isolates, which were not initially classified as Alternaria spp. or Penicillium spp. are from now on referred to as "other", while isolates which could not be identified are "unidentified".

\section{Preharvest isolations}

Dry and mouldy core rot symptoms preharvest

In 2009 fungal isolates collected from 63 infected apples were identified morphologically to genus level (Table 1; Suppl. Table 1). In eight instances Alternaria species were co-isolated with Penicillium species from DCR or MC symptoms (Suppl. Table 1). Alternaria spp. were most frequently isolated from DCR (53\%) and MC (66\%) symptoms followed by Penicillium spp. with 37 and 26\%, respectively. In 2010, 79 fungi were isolated from 800 symptomless fruit sampled (Suppl. Table 1) and identified as either Alternaria (87\% DCR and $89 \%$ MC) or Penicillium species (13\% DCR and $11 \% \mathrm{MC})$.

Table 1

Incidence of core rot fungal genera (number of isolates with percentage in brackets) in one Koue Bokkeveld orchard from symptomatic dry core rot (DCR), mouldy core (MC) or wet core rot (WCR) infected apples

\begin{tabular}{|c|c|c|c|c|c|}
\hline Season & Pathogen* & Source** & DCR & MC & WCR \\
\hline \multirow{3}{*}{2009} & Alternaria spp. & PRE & $10(53 \%)$ & $23(66 \%)$ & 0 \\
\hline & Penicillium spp. & PRE & $7(37 \%)$ & $9(26 \%)$ & $9(100 \%)$ \\
\hline & unidentified & PRE & 0 & 0 & 0 \\
\hline \multirow{4}{*}{2009} & Alternaria spp. & POST & $13(57 \%)$ & $44(53 \%)$ & $2(10 \%)$ \\
\hline & Penicillium spp. & POST & $1(4 \%)$ & $9(11 \%)$ & $13(62 \%)$ \\
\hline & other & POST & $4(17 \%)$ & $6(7 \%)$ & $3(14 \%)$ \\
\hline & unidentified & POST & $5(22 \%)$ & $23(28 \%)$ & $3(14 \%)$ \\
\hline \multirow{4}{*}{2010} & Alternaria spp. & PRE & $45(87 \%)$ & $24(89 \%)$ & $8(62 \%)$ \\
\hline & Penicillium spp. & PRE & $7(13 \%)$ & $3(11 \%)$ & $5(38 \%)$ \\
\hline & other & PRE & 0 & 0 & 0 \\
\hline & unidentified & PRE & 0 & 0 & 0 \\
\hline \multirow{3}{*}{2010} & Penicillium spp. & POST & $8(11 \%)$ & $5(7 \%)$ & $3(9 \%)$ \\
\hline & other & POST & $33(46 \%)$ & $12(17 \%)$ & $17(50 \%)$ \\
\hline & unidentified & POST & $25(35 \%)$ & $34(49 \%)$ & $13(38 \%)$ \\
\hline \multirow{2}{*}{ Total } & Alternaria spp. & PRE + POST & $74(45 \%)$ & $110(51 \%)$ & $11(14 \%)$ \\
\hline & Penicillium spp & $\mathrm{PRE}+\mathrm{POST}$ & $23(14 \%)$ & $26(12 \%)$ & $30(39 \%)$ \\
\hline
\end{tabular}

*Pathogens were morphologically identified either as Alternaria sp. or Penicillium sp., other species were grouped as "other", nonviable hyphae were categorised "unidentified"

**Source of core rot pathogen: either from apples collected from the orchard preharvest (PRE) or postharvest (POST)

Wet core rot preharvest

In 2009, from the 200 sampled symptomless apples, nine isolates were identified as Penicillium spp. (100\%). Alternaria species were not isolated. In 2010, eight out of a total of 13 isolates collected from 800 symptomless apples were identified as Alternaria species (62\%) while the remaining isolates were Penicillium species (5; $38 \%$ ).

\section{Post-harvest isolations}

Dry and mouldy core rot postharvest

In 2009, a total of 126 isolates from core rot infected apples were identified in the 1000 sampled symptomless apples. Alternaria species comprised the majority of the isolates for DCR and MC with 13 (57\%) and 44 (53\%) respectively. A single Penicillium isolate was associated with DCR (4\%) and nine isolates (11\%) with MC. Four DCR and six MC isolates were grouped as 'other' while 28 isolates were unidentified. In 2010, 33 DCR (46\%) and 12 MC (17\%) isolates out of 142 isolates collected from infected apples, were predominantly associated with other fungal genera. Six DCR (8\%) and 19 MC isolates (27\%) were identified as Alternaria. Eight DCR and five MC isolates were identified as Penicillium spp., respectively. A further 25 isolates caused DCR (35\%) and 34 isolates caused MC (49\%) and were unidentified.

\section{Wet core rot postharvest}

In 2009, 13 Penicillium spp. (62\%) and two Alternaria spp. (10\%) isolates were identified from WCR symptoms. Three isolates (14\%) were identified as "other" (meaning other fungal species, not Alternaria spp. or Penicillium spp.) and a further three (14\%) were unidentified due to nonviable hyphae. In 2010 , three isolates (9\%) were identified as Penicillium spp., while only one isolate (3\%) was identified as an Alternaria spp. The other isolations (50\%) were morphologically identified as the following: Botryosphaeria, Botrytis, Epicoccum, Fusarium, Gliocladium, Phoma, Phomopsis, Ulocladium and Verticillium (data not shown). Thirteen isolates (38\%) were unidentified.

\section{Inoculum sources}

Penicillium species were identified from samples taken from the air, mummies and mites and a subset of 36 isolates were identified using molecular methods. Alternaria species were identified from air samples only (data not shown), and a subset of nine samples were included.

\section{Molecular identification of the Alternaria and Penicillium species}

The 49 Alternaria spp. isolates selected for species identification included 10 isolates from pre- and post-harvest symptomatic fruit, from both seasons, and nine isolates from the air inoculum. Alternaria spp. were neither isolated from apple mummies nor from mites associated with the mummies. The 97 Penicillium isolates selected for molecular species identification included 10 isolates from pre- and post-harvest symptomatic fruit and 10 isolates each from the mummies and mites for each season. Ten Penicillium isolates, collected from air inoculum in orchard B in 2009 were included. As the trees in orchard B were removed in 2010, seven Penicillium isolates from the air inoculum from an alternative 'Starking' orchard located within a $10 \mathrm{~km}$ radius in the same valley were included ("orchard C").

Fallen fruit were collected preharvest and postharvest for the seasons 2009 and 2010. Isolations were made from infected tissue of fruit with WCR symptoms. Nine and five Penicillium spp. samples were collected pre-harvest and 13 and three samples were collected post-harvest in 2009 and 2010, respectively.

Alternaria species associated with DRC and MC

Isolates Alt10 (pre-harvest collection 2009) and Alt16 (STE-U 8409; post-harvest collection 2009) were identified through a Genbank Basic Local Alignment Search Tool search for nucleotides (BLASTn) (Clark et al. 2016) and phylogenetic analysis as A. infectoria and A. eureka Simmons respectively (Fig. 1; Suppl. Table 2). The Alternaria 
species, A. alternata, A. arborescens and A. tenuissima could not be separated using sequencing of the ITS region (Fig. 1), thus phylogenetic (parsimony) analysis was conducted on each of the following genetic loci: endoPG, OPA1-3 and OPA2-1. The sequences obtained from GenBank (Suppl. Table 2) are representative type strains of $A$. alternata EGS34-016 and A. perangusta EGS44-160 being ex-type strains and A. arborescens EGS39-128 and A. dumosa EGS45-007 being holotype strains (Simmons 2007).

A partition homogeneity test (PHT) was performed on the invariant characters of the three combined datasets (endoPG, OPA1-3 and OPA2-1) as well as the combination of individual genetic loci with another locus (endoPG and OPA1-3, endoPG and OPA2-1, and OPA $1-3$ and OP2-1). Each of the combinations gave a $P$ value of 0.001 in the PHT. Parsimony and Bayesian analysis were conducted on the combined dataset.

The phylogeny of the combined datasets resulted in 10 clades, each containing the sequence of a GenBank reference isolate (Fig. 2). Two equally parsimonious trees were recovered. Significant Bayesian probability values $(>60 \%)$ are shown together with the most likelihood (bootstrap) values of the parsimony analysis. Clade 1 consists of the reference strains A. turkisafria EGS 44-159 and A. perangusta EGS 44-160. Clade 2 contains the reference strain A. dumosa EGS 45-007, Clade 3 contains the reference strain A. alternata EGS 45-002, and Clade 4 contains the ex-type reference strain A. alternata EGS 34-016 as well as the reference isolates A. alternata EGS 34-039 and EGS 45-008. Clades 5, 6 and 7 contained the reference strains A. alternata EGS 45-062, A. tenuissima EGS 34-015 and A. alternata EGS 45-010, respectively. Clade 8 contains the reference strain A. arborescens EGS 39-128. The outgroup sequences were A. gaisen EGS 37-1321 (Clade 9) and A. longipes EGS 30-033 (Clade 10). The representative strains and the isolates identified as A. infectoria and E. eureka could not be sequenced for the endoPG region or for the anonymous region datasets, OPA1-3 and OPA2-1, due to a lack of PCR amplification with the primers used.

The Alternaria species identified morphologically could not be separated into distinct clades by using phylogenetic analysis of the endoPG region alone. This analysis separated the isolates into three species-groups, group one constituted A. arborescens and A. dumosa, group two A. alternata, and group three $A$. tenuissima. For the preharvest season's sample collections $(2009,2010)$ and the air inoculum the species-groups $A$. dumosa/A. tenuissima had the highest occurrence with 13 out of 21 samples, while the $A$. arborescens species-group occurred most frequently for both post-harvest seasons with eight out of 16 tested samples.

The genetic region, OPA1-3, could not distinguish between $A$. alternata and A. tenuissima nor could $A$. alternata be distinguished from various other reference sequences. Alternaria arborescens, which occurred most frequently post-harvest, was the only species-group that could be distinguished from the other reference sequences with the genetic region, OPA2-1. Alternaria alternata clustered with reference sequences including A. tenuissima, A. dumosa and A. gaisen. However, isolates could not be separated from each other in this clade.

The three genetic regions were combined in a multi-gene phylogeny which could distinguish between the various Alternaria species. Alternaria arborescens occurred frequently in the post-harvest subset of samples. Alternaria alternata and A. tenuissima could be separated into distinct clades, with A. alternata occurring in all the sources more frequently during pre-harvest. Alternaria dumosa was most frequently detected from the aerial samples. Only one isolate from the 2010 pre-harvest collection was identified as A. tenuissima.

\section{Pathogenicity of Alternaria species}

Five days after inoculation the species that appeared the most virulent on 'Starking' apples was $A$. arborescens with an average lesion size of $11.03 \mathrm{~mm}( \pm 2.79,95 \% \mathrm{CI})$. The species $A$. alternata, A. infectoria and A. eureka had a smaller average lesion size of $9.71 \mathrm{~mm}( \pm 2.79), 8.74 \mathrm{~mm}( \pm 3.14)$, and $6.78 \mathrm{~mm}( \pm 2.72)$, respectively (data not shown). After $10 \mathrm{~d}$ incubation there was no significant difference between A. alternata $(13.90 \mathrm{~mm}, \pm 2.79)$, A. infectoria $(12.56 \mathrm{~mm}, \pm 3.14)$, A. arborescens $(20.01 \mathrm{~mm}, \pm 2.72)$ and two of the three tested A. tenuissima isolates $(20.2 \mathrm{~mm}, \pm 2.26)$ had significantly larger lesions. While $A$. eureka and one of the $A$. tenuissima isolates appeared less virulent ( $7.11 \mathrm{~mm}, \pm 2.72$; Fig. 4). While $A$. arborescens, A. alternata, and A. infectoria often colonised the core of the inoculated apples, $A$. eureka was pathogenic in the flesh of the apple, but frequently did not colonise the core (Fig. 6). Occasionally a dry corky lesion surrounding the core was observed for $A$. eureka inoculated apples. Alternaria alternata produced classic DCR symptoms of dry, corky lesions, while A. arborescens presented brown, spongy lesions, and A. infectoria lesions appeared dark brown to black. Re-isolation from the edge of the lesion confirmed pathogenicity of the tested isolates thereby fulfilling Koch's postulates.

Fig. 6

Alternaria spp. isolates in pathogenicity test on 'Starking' apples. Isolates used were a STE-U8409 (A. eureka) showing brown lesion only extending into flesh, b STE-U8409 ( $A$. eureka) lesion extending into core, c STE-U7632 (A. alternata) with dry, corky core colonisation, d STE-U7634 (A. infectoria) with black core rot, and e STE-U7636 (A. arborescens) with spongy brown lesion, $\mathbf{f}$ negative control with sterile toothpick
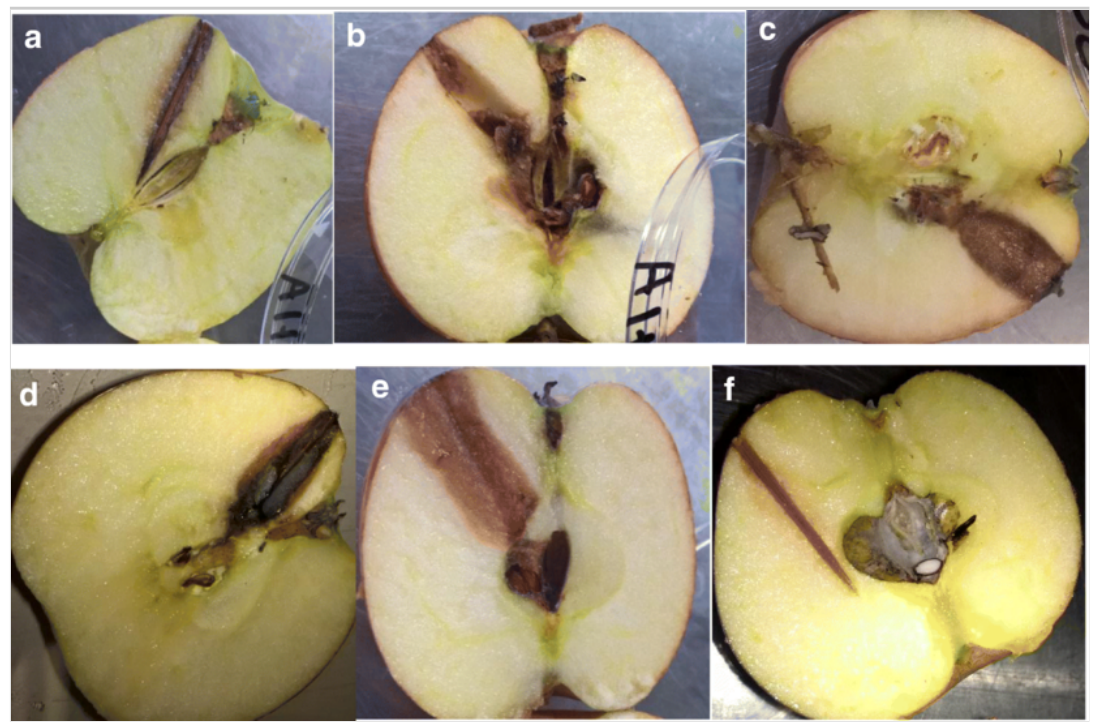

Penicillium spp. associated with pre-and post-harvest wet core rot

The identification of Penicillium species from pre- (fallen fruit) and post-harvest WCR were undertaken using the partial beta-tubulin PCR-RFLP method and comparing the isolates' banding patterns with the identified species of Van der Walt et al. (2010). The following Pencillium species were identified from WCR isolations: P. expansum, P. species (aff. dendriticum), P. ramulosum, P. rugulosum, P. chermesinum, P. glabrum and $P$. species (aff. cecidicola). Of the 60 samples collected pre-harvest and the 63 samples post-harvest, 13.33 and $7.94 \%$ could not be identified to species level using the beta-tubulin PCR-RFLP, some of which were further characterised using ITS and/or beta tubulin sequencing (provided they were successfully single spored).

The two most frequently isolated Penicillium species from WCR were $P$. expansum and $P$. ramulosum with $P$. ramulosum having the highest incidence pre-harvest and $P$. expansum the highest incidence post-harvest. Penicillium expansum incidence increased from $15 \%$ pre-harvest to $52 \%$ post-harvest, while $P$. ramulosum incidence decreased from 50 to $29 \%$ pre- to post-harvest. Penicillium glabrum was only isolated pre-harvest and P. rugulosum occurred only during post-harvest. Penicillium sp. (aff. cecidicola) occurred at low frequencies preharvest in 2010 (Table 2). 
The population distribution (\%) of the identified Penicillium isolates for each collection source using beta-tubulin PCR-RFLP

\begin{tabular}{|c|c|c|c|c|c|c|c|c|c|c|}
\hline Species name & $\begin{array}{l}\text { Pre-harvest } \\
\quad 2009\end{array}$ & $\begin{array}{l}\text { Pre-harvest } \\
\quad 2010\end{array}$ & $\begin{array}{c}\text { Post-harvest } \\
2009\end{array}$ & $\begin{array}{l}\text { Post-harvest } \\
2010\end{array}$ & $\underset{2009}{\text { Mummies }}$ & $\underset{2010}{\text { Mummies }}$ & $\begin{array}{l}\text { Mites } \\
2009\end{array}$ & $\begin{array}{l}\text { Mites } \\
2010\end{array}$ & $\underset{2010}{\operatorname{Air} A^{*}}$ & $\begin{array}{c}\text { Air B* } \\
2010\end{array}$ \\
\hline $\mathbf{n}$ & 9 & 10 & 13 & 3 & 10 & 10 & 10 & 10 & 11 & 8 \\
\hline Clonostachys sp. & $1(11 \%)$ & 0 & 0 & 0 & 0 & 0 & 0 & 0 & 0 & 0 \\
\hline P. brevicompactum & 0 & 0 & 0 & 0 & 0 & 0 & 0 & $1(10 \%)$ & 0 & 0 \\
\hline P. cecidicola & $1(11 \%)$ & 0 & 0 & 0 & 0 & 0 & $1(10 \%)$ & 0 & $1(9 \%)$ & $1(13 \%)$ \\
\hline P. crustosum & 0 & 0 & $1(8 \%)$ & 0 & 0 & 0 & 0 & 0 & 0 & 0 \\
\hline P. expansum & $2(22 \%)$ & $1(10 \%)$ & $2(15 \%)$ & $1(33 \%)$ & $7(70 \%)$ & $6(60 \%)$ & $4(40 \%)$ & $4(40 \%)$ & $7(45 \%)$ & $7(88 \%)$ \\
\hline P. glabrum & 0 & 0 & 0 & 0 & 0 & 0 & $1(10 \%)$ & 0 & $2(18 \%)$ & 0 \\
\hline P. novae-zeelandiae & 0 & 0 & 0 & 0 & 0 & 0 & 0 & 0 & $1(9 \%)$ & 0 \\
\hline P. paneum & 0 & 0 & 0 & 0 & $1(10 \%)$ & 0 & 0 & 0 & 0 & 0 \\
\hline P. ramulosum & $4(44 \%)$ & $6(60 \%)$ & $8(61 \%)$ & $2(66 \%)$ & 0 & 0 & 0 & 0 & 0 & 0 \\
\hline P. rugulosum & 0 & 0 & 0 & 0 & 0 & $2(20 \%)$ & 0 & 0 & 0 & 0 \\
\hline P. solitum & 0 & $1(10 \%)$ & 0 & 0 & 0 & 0 & 0 & 0 & 0 & 0 \\
\hline $\begin{array}{l}P . \mathrm{sp}_{\text {. (aff. }} \\
\text { cecidicola) }\end{array}$ & 0 & $1(10 \%)$ & 0 & 0 & 0 & 0 & 0 & 0 & 0 & 0 \\
\hline $\begin{array}{l}\text { Other Penicillium } \\
\text { sp. }\end{array}$ & $1(11 \%)$ & $1(10 \%)$ & $2(15 \%)$ & 0 & $2(20 \%)$ & $2(20 \%)$ & $4(40 \%)$ & $5(50 \%)$ & $2(18 \%)$ & 0 \\
\hline
\end{tabular}

*Samples were obtained from two orchards in the Ceres region (A and B), while all other samples pre and postharvest were collected from orchard B

The ITS gene tree divided the references and eight Penicillium sequences into 13 clades. The majority of the Penicillium isolates were identified as $P$. ramulosum (Clade 1) and $P$. expansum (Clade 4). Forty-two Penicillium isolates' ITS sequences were identical to the $P$. expansum Genbank reference sequence AB479309 (only ten isolates represented in the phylogenetic tree; Fig. 3). Other isolates were identified as $P$. sp. (aff. brevicompactum), P. sp. (aff. cecidicola), P. crustosum, P. glabrum, P. sp. (aff. glabrum), P. novae-zeelandiae, P. paneum, P. rugulosum and P. solitum. Two isolates, initially classified as Penicillium sp., clustered with very good bootstrap support $(100 \%)$, as Clonostachys sp. (Clade 12). Talaromyces helicus was used as outgroup to root the phylogenetic ITS tree (Fig. 3). Partial beta tubulin sequence analysis identified isolate STE-U 8431 as Penicillium polonicum Zaleski, isolate STE-U 8432 and STE-U 8433 as P. crustosum, and STE-U 8588 was identified as Clonostachys rosea (Link) Schroers, Samuels, Seifert \& W. Gams (Fig. 4). The P. polonicum isolate and the C. rosea isolate were shown to be less or equally pathogenic in comparison to the two tested P. crustosum isolates in the 'Starking' pathogenicity test (Fig. 5).

The population distribution of Penicillium sp. was determined from each collection pre- and post-harvest as well as for each of the inoculum sources, air, mites and mummies (Table 2). Penicillium expansum was the only species that occurred consistently in all seasons and tested inoculum sources and P. ramulosum was detected in symptomatic fruit pre- and post-harvest, but not in potential inoculum sources (Table 2). Small percentages of the other species occurred throughout the collection sources (Table 2).

\section{Discussion}

Fungi isolated from pre- and post-harvest core rot symptomatic fruit and inoculum sources were identified to genus level using morphological characteristics. These included the two most frequently isolated fungi from core rot symptomatic fruit namely the genera Alternaria and Penicillium. It was not possible to identify these fungi to species level using only morphological characteristics, thus molecular tools were implemented to assist in the identification of the Alternaria and Penicillium species. Phylogenetic studies have shown that the Alternaria complex contains seven sections (Woudenberg et al. 2013, 2015). Eleven phylogenetic species clades and one (Alternaria alternata) species now comprise the genus Alternaria. Earlier studies have attempted to distinguish between small-spored Alternaria species such as $A$. alternata, A. tenuissima or $A$. arborescens within new genetic regions, but without success (Peever et al. 2004, 2005; Andrew et al. 2009). In this study, Alternaria spp. were identified as A. eureka, A. dumosa, A. infectoria, and the other three common small-spored Alternaria species (A. alternata, A. arborescens and A. tenuissima) were also present. Only the first three were identified using the ITS locus, since small-spored Alternaria species are difficult to distinguish using common "barcoding loci". Although Alternaria infectoria could be distinguished from species of the A. alternata complex using ITS sequence analysis due to a 26 bp insert (de Hoog and Horré 2002). Alternaria eureka, a species not previously identified as a core rot pathogen, was identified from the 2009 post-harvest collection in this study and confirmed to be pathogenic on 'Starking' apples.

The combined genetic loci endoPG, OPA1-3 and OPA2-1 further enabled species identification of A. arborescens, A. alternata, A. dumosa and A. tenuissima. Peever et al. (2004) reported a partition homogeneity test (PHT) performed on the combination of the loci into a single phylogeny resulted in a significant $P$ value of 0.002 . Combination of the datasets was therefore controversial, since Cunningham (1997) stated that the accuracy of the phylogenetic analysis increases with an increase in P value (above 0.01), and if the P value of the PHT is lower than 0.001 the combined data suffers. Due to this controversy about the multi-gene phylogeny with the P value of 0.001 observed in this study, the datasets were analysed separately to establish whether each of the genetic loci could distinguish between the Alternaria sp. observed from apple core rot as well as other small-spored Alternaria sp. reference isolates. The separate datasets, endoPG and OPA1-3 gave well defined clades, separating $A$. arborescens from $A$. alternata. In the endoPG dataset $A$. tenuissima clustered together with the reference isolate $A$. dumosa, a species reported on citrus (Fazlikhani and Soleimani 2013). Various A. alternata reference sequences separated into different clades of the phylogenetic tree (Fig. 2). In the OPA1-3 dataset the $A$. tenuissima reference isolate clustered together with the A. alternata EGS45-062 reference sequence in a well-supported clade. The OPA2-1 dataset distinguished between A. arborescens and A. tenuissima / A. alternata but the bootstrap values were not well supported and the reference isolates A. gaisen, A. dumosa, A. tenuissima and various $A$. alternata isolates grouped together to form one clade. Alternaria arborescens was consistently detected between the three analyses for each of the collection sources.

The phylogenetic results of endoPG and OPA1-3 can be compared with one another to establish which genetic loci distinguishes better between $A$. arborescens, A. tenuissima and $A$. alternata. EndoPG had higher values for the consistency, retention and rescaled consistency indexes, but had lower tree length values and parsimony-informative characters compared to OPA1-3. EndoPG is a known virulence factor, and therefore most likely under selection pressure due to host-pathogen interactions, whereas OPA1-3 is an anonymous region. OPA $1-3$ was found to be more variable between the species, which increases its chance to separate the species from one another, but variation within the species also occurred. This results in isolates from the same species grouping in different clades of the phylogenetic tree. The combined dataset has low bootstrap values causing certain clades to collapse. This decreases the ability of the phylogenetic tree to distinguish between specific Alternaria species except for $A$. arborescens. The analysis using ITS and multilocus phylogeny of the pre- harvest isolates identified the following species $A$. infectoria, A. alternata, A. arborescens, A. dumosa and $A$. tenuissima, Whereas $A$. infectoria and $A$. tenuissima were not detected in postharvest samples. In the combined analysis the air inoculum samples were identified as $A$. alternata, A. arborescens and A. dumosa (Fig. 2). Previously only A. arborescens, A. infectoria, A. tenuissima and unidentified Alternaria sp. had been reported from South African Alternaria dry core rot on apples (Kang et al. 2002; Serdani et al. 2002). Serdani et al. (2002) also concluded that $A$. tenuissima was the most prevalent species to cause DCR in South Africa. Interestingly a study of core rot pathogens from China identified A. alternata, A. arborescens, A. infectoria and A. tenuissima (Gao et al. 2013). The same species groups were found to infect citrus and walnut (Peever et al. 2004, 2005; Hong et al. 2006). Alternaria tenuissima has also been reported to cause dry core rot on apples in the USA (Kou et al. 2014). The A. eureka isolate (STE-U 8409, Alt16), that had been isolated from postharvest DCR symptomatic fruit, was confirmed to be pathogenic on 'Starking' apples, but did not cause core rot symptoms as often as the other tested species A. arborescens, A. alternata and A. infectoria under the tested conditions. Further investigations into the frequency of occurrence of this pathogen in a larger number of orchards would be required to establish the relevance of this new core rot pathogen.

To prevent decay caused by $A$. alternata and related fungal species, integrated control recommendations (together with orchard fungicide applications and breeding efforts) include the disinfection of wooden picking bins, careful handling of fruit to prevent wounds, rapid postharvest removal of field heat from fruit, and addition of chlorine to the 
The two main species isolated, from both pre- and post-harvest WCR, were P. expansum and P. ramulosum. Penicillium expansum occurred less frequently than P. ramulosum pre- and post-harvest. Penicillium expansum was distributed through all of the collection sources, with high incidence in each of the inoculum sources, its pathogenicity is well known (van der Walt et al. 2010; Villanova et al. 2012). Penicillium ramulosum occurred in samples from the pre- and post-harvest collection, but did not occur in any other inoculum source. The other species causing WCR preharvest were $P$. sp. (aff. brevicompactum), P. sp. (aff. cecidicola), and P. polonicum while P. crustosum was found to cause WCR post-harvest. Van der Walt et al. (2010) isolated P. ramulosum and P. expansum frequently from pre-harvest WCR symptoms. Their and our results suggests that prior to harvest the fruit is infected with P. ramulosum and some of the fruit drop prematurely due to the infection of the fungi. The infected fruit that does not drop prematurely ripens normally and is harvested with the rest of the orchard. These fungi remain latent until after storage, when favourable conditions increase the infection rate. Penicillium expansum, an opportunistic fungus infecting citrus fruits, apples, pears and cherries post-harvest through small wounds is the main causal organism of 'blue mould'. Blue mould produces the toxin patulin that is harmful in apple juice and apple products. Patulin is produced by the fungus when it rots the host. (Sanderson and Spotts 1995; Pitt and Hocking 1997; Morales et al. 2007). AQ4

Other Penicillium species confirmed through sequence analysis were identified as $P$. crustosum, P. glabrum, P. novae-zeelandiae, P. paneum, P. polonicum, P. rugulosum, P. solitum, $P$. sp. (aff. brevicompactum), P. sp. (aff. cecidicola), and P. sp. (aff. dendriticum). Similarly, P. glabrum, P. sp. (aff. cecidicola) and P. sp. (aff. dendriticum) were identified in the study by van der Walt et al. (2010) in South African wet core rot samples. Van der Walt furthermore identified $P$. chermesinum, which was not detected in the current study. Gao et al. (2013) identified P. chrysogenum Thom, P. expansum, P. paneum, P. viridicatum associated with WCR symptoms on Fuji apples in China. Penicillium polonicum has previously been shown to cause storage rot on onions (Çakir and Maden 2015). This is the first report of $P$. polonicum pathogenic on apple. Clonostachys rosea is a biocontrol agent for soil borne pathogens, but has been described as weak pathogen on fruit and causes potato dry rot (Theron and Holz 1991; Pratella and Mari 1993). This is the first report of C. rosea as pathogen on apple. Weak colonisation capability on apples has been reported for other fungi, used as biocontrol agents on other crops, possibly due to cold sensitivity of the pathogens, which could prevent losses though decay (Conway 1983; Pratella and Mari 1993). This should be tested in larger studies with virulence tests involving multiple isolates of the reported species that were associated with core rot in this study.

Several mycotoxin producing Penicillium species were detected in this study, i.e. P. crustosum, which has frequently been described as apple pathogen (Frisvad and Samson 2004; Vico et al., 2014; Rharmitt et al. 2016). In South African pears and apples P. expansum, followed by P. crustosum were amongst the most pathogenic Penicillium species causing postharvest decay on apples (Louw and Korsten 2014). Penicillium novae-zeelandiae was isolated from the air inoculum. This species has previously been described as endophyte from Vitis vinifera L. and Quercus suber L. (Serra et al. 2008; Houbraken et al. 2011) and produces patulin in culture (Alfaro et al. 2003). There has been no previous mention of this species in association with apple core rot or any other plant disease. As pathogenicity tests were not done using this species its pathogenicity on apples is currently unknown. Penicillium paneum and P. rugulosum were detected in one and two samples of apple mummies, respectively, and no pathogenicity tests were conducted to verify if this species would cause core rot on apples. The occurrence of $P$. solitum preharvest causing blue mould of apple has previously been shown (Sanderson and Spotts 1995; Pianzzola et al. 2004).

AQ5

AQ6

Combrink et al. (1985) identified P. funiculosum as the main Penicillium species associated with core rot in South Africa, however none of the isolates from this study had sequence similarity to $P$. funiculosum. This could either be due to a too small sample size, the fungus not occurring in the sampled orchards or isolates previously identified morphologically as P. funiculosum are now, using molecular techniques, identifying as different Penicillium species.

Previous studies on WCR established that DPA, which was used to prevent superficial scald, reduced the water tension of the flume water, which could have allowed contaminated water to flow into the core regions of susceptible cultivars contributing to an increase in core rot infection (Combrink and Ginsburg 1973; Combrink et al. 1985; Spotts et al. 1988).

Wet core rot is not exclusively caused by $P$. expansum as previously reported, but through a wide range of different species, including $P$. ramulosum pre-harvest. Although the incidence of the Penicillium species that occurred in both pre- and post-harvest isolations differed, a link could be established between the species that occurred in both preand post-harvest WCR. Managing this link between pre- and post-harvest can be problematic. An integrated management strategy should be implemented where chemical control should be used in combination with sanitation practices, both in the orchard and in the pack house, to reduce the inoculum build-up of the same species.

\section{Acknowledgments}

This study was financially supported through project and MSc bursary funding by HORTGRO and the National Research Foundation (THRIP). We would like to thank the South African fruit growers in the Witzenberg Valley for participation in this study.

\section{Electronic supplementary material}

\section{ESM 1 ESM $2 \quad$ ESM 3}

(PDF $292 \mathrm{~kb})$ (DOCX $29 \mathrm{~kb})($ DOCX $28 \mathrm{~kb})$

\section{References}

AQ7

Alfaro, C., Urios, A., González, M. C., Moya, P., \& Blanco, M. (2003). Screening for metabolites from Penicillium novae-zeelandiae displaying radical-scavenging activity and oxidative mutagenicity: Isolation of gentisyl alcohol. Mutation Research, 539, 187-194.

Amiri, A., \& Bompeix, G. (2005). Diversity and population dynamics of Penicillium spp. in apples in pre- and postharvest environments: consequences for decay development. Plant Pathology, 54, 74-81.

Andersen, B., Sørensen, J. L., Nielsen, K. F., Gerrits-van den Ende, B., \& de Hoog, S. (2009). A polyphasic approach to the taxonomy of the Alternaria infectoria speciegroup. Fungal Genetics and Biology, 46, 642-656.

Andrew, M., Peever, T. L., \& Pryor, B. M. (2009). An expanded multilocus phylogeny does not resolve morphological species within the small-spored Alternaria species complex. Mycologia, 101, 95-109.

Barnett, H. L., \& Hunter, B. B. (1998). Illustrated genera of imperfect fungi (4th ed.). St. Paul: APS Press, The American Phytopathological Society.

Berbee, M. L., Payne, B. P., Zhang, G., Roberts, R. G., \& Turgeon, B. G. (2003). Shared ITS DNA substitutions in isolates of opposite mating type reveal a recombining history for three presumed asexual species in the filamentous ascomycete genus Alternaria. Mycological Research, 107, $169-182$.

Çakir, E., \& Maden, S. (2015). First report of Penicillium polonicum causing storage rots of onion bulbs in Ankara province, Turkey. New Disease Reports, $32,24$. https://doi.org/10.5197/j.2044-0588.2015.032.024 
Clark, K., Karsch-Mizrachi, I., Lipman, D. J., Ostell, J., \& Sayers, E. W. (2016). GENBANK. Nucleic Acids Research, 44(Database issue), D67-D72. Published online 2015 Nov 20.. https://doi.org/10.1093/nar/gkv1276.

Combrink, J. C., \& Ginsburg, L. (1973). Core rot in Starking apples - A preliminary investigation into the origin and control. Deciduous Fruit Grower, 23 , 16-19.

Combrink, J. C., Kotzé, J. M., Wehner, F. C., \& Grobbelaar, C. J. (1985). Fungi associated with core rot of Starking apples in South Africa. Phytophylactica, 17, 81-83.

Combrink, J. C., Grobbelaar, C. J., \& Visagie, T. R. (1987). Effect of diphenylamine emulsifiable concentrations on the development of wet core rot in Starking apples. Deciduous Fruit Grower, 37, 97-99.

Conway, W. A. (1983). Trichoderma harzianum. A possible cause of apple decay in storage. Plant Disease Report, 67, $316-317$.

Cunningham, C. W. (1997). Can three incongruence tests predict when data should be combined? Molecular Biology and Evolution, 14, 733-740.

de Hoog, G. S., \& Horré, R. (2002). Molecular taxonomy of the Alternaria and Ulocladium species from humans and their identification in the routine laboratory. Mycoses, 45, 259-276.

de Hoog, G. S., \& van den Ende, A. H. G. (1998). Molecular diagnostics of clinical strains of filamentous basidiomycetes. Mycoses, 41, $183-189$.

de Kock, S. L., Visagie, T. R., \& Combrink, J. C. (1991). Control of core rot in Starking apples. Deciduous Fruit Grower, 41, $20-22$.

Ellis, M. A., \& Barrat, J. G. (1983). Colonization of delicious apple fruits by Alternaria spp. and effect of fungicide sprays on moldy-core. Plant Disease, 67, $150-152$.

Farris, J. S., Källersjö, M., Kluge, A. G., \& Bult, C. (1994). Testing significance of incongruence. Cladistics, 10, 315-319.

Fazlikhani, L., \& Soleimani, M. J. (2013). First report of Alternaria dumosa causing orange leaf spot disease in Iran. New Disease Reports, $27,24$. https://doi.org/10.5197/j.2044-0588.2013.027.024 Accessed 3 March 2017.

Frisvad, J. C., \& Samson, R. A. (2004). Polyphasic taxonomy of Penicillium subgenus Penicillium a guide to identification of food and air-borne terverticillate Penicillia and their mycotoxins. Studies in Mycology, 49, 1-174.

Gao, L. L., Zhang, Q., Sun, X. Y., Jiang, L., Zhang, R., Sun, G. Y., Zha, Y. L., \& Biggs, A. R. (2013). Etiology of moldy core, core browning, and core rot of Fuji apple in China. Plant Disease, 97, 510-516.

Glass, N. L., \& Donaldson, G. C. (1995). Development of primer sets designed for use with the PCR to amplify conserved genes from filamentous ascomycetes. Applied and Environmental Microbiology, 61, 1323-1330.

Harrison, C. J., \& Langdale, J. A. (2006). A step by step guide to phylogeny reconstruction. The Plant Journal, 45, 561-572.

Hong, C. X., Michailides, T. J., \& Holtz, B. A. (2000). Mycoflora of stone fruit mummies in California orchards. Plant Disease, 84, 417-422.

Hong, S. G., Liu, D., \& Pryor, B. M. (2005). Restriction mapping of the IGS region in Alternaria spp. reveals variable and conserved domains. Mycological Research, 109, $87-95$.

Hong, S. G., Maccaroni, M., Figuli, P. J., Pryor, B. M., \& Belisario, A. (2006). Polyphasic classification of Alternaria isolated from hazelnut and walnut fruit in Europe. Mycological Research, 110, 1290-1300.

Hortgro Statistics (2016). URL: http://www.hortgro.co.za/wp-content/uploads/2017/06/HORTGRO-Key-Deciduous-Fruit-Statistics-2016.pdf

Houbraken, J., Frisvad, J. C., \& Samson, R. A. (2011). Taxonomy of Penicillium section Citrina. Studies in Mycology, 70, 53-138.

Isshiki, A., Akimitsu, K., Yamamoto, M., \& Yamamoto, H. (2001). Endopolygalacturonase is essential for citrus black rot caused by Alternaria citri but not brown spot caused by Alternaria alternata. Molecular Plant-Microbe Interactions, 14, 749-757.

Janisiewicz, W. J., Leverentz, B., Conway, W. S., Saftner, R. A., Reed, A. N., \& Camp, M. J. (2003). Control of bitter rot and blue mold of apples by integrating heat and antagonist treatments on 1-MCP treated fruit stored under controlled atmosphere conditions. Postharvest Biology and Technology, 29, 129-143.

Kang, J. C., Crous, P. W., Mchau, G. R. A., Serdani, S., \& Song, S. M. (2002). Phylogenetic analysis of Alternaria spp. associated with apple core rot and citrus black rot in South Africa. Mycological Research, 106, 1151-1162.

Katoh, K., \& Toh, H. (2008). Recent developments in the MAFFT sequence alignment programme. Bioinformatics, 9, $286-298$.

Kim, Y. K., \& Xiao, C. L. (2008). Distribution and incidence of Sphaeropsis rot in apple in Washington State. Plant Disease, 92, 940-946.

Kou, L. P., Gaskins, V. L., Luo, Y. G., \& Jurick II, W. M. (2014). First report of Alternaria tenuissima causing postharvest decay on apple fruit from cold storage in the United States. Plant Disease, 98(5), 690.

Kusaba, M., \& Tsuge, T. (1995). Phylogeny of Alternaria fungi known to produce host-specific toxins on the basis of variation in internal transcribed spacers of ribosomal DNA. Current Genetics, 28, 491-498.

Lawrence, D. P., Park, M. S., \& Pryor, B. M. (2012). Nimbya and Embellisia revisited, with nov. comb for Alternaria celosiae and A. perpunctulata. Mycological Progress, 11, 799-815.

Lee, S. B., \& Taylor, J. W. (1990). Isolation of DNA from fungal mycelia and single spores. In M. A. Innis, D. H. Gelfand, J. J. Sninsky, \& T. J. White (Eds.), PCR Protocols: A guide to methods and applications (pp. 282-287). San Diego: Academic Press.

Leverentz, B., Conway, W. S., Janisiewicz, W. J., Saftner, R. A., \& Camp, M. J. (2003). Effect of combining MCP treatment, heat treatment, and biocontrol on the reduction of postharvest decay of 'golden delicious' apples. Postharvest Biology and Technology, 27, 221-223.

Lobuglio, K. F., Pitt, J. I., \& Taylor, J. W. (1993). Phylogenetic analysis of two ribosomal DNA regions indicates multiple independent losses of a sexual Talaromyces state among asexual Penicillium species in the subgenus Biverticillium. Mycologia, 85, 592-604.

Lobuglio, K. F., Pitt, J. I., \& Taylor, J. W. (1994). Independent origins of the synnematous Penicillium species, P. duclauxii, P. clavigerum and P. vulpinum, as assessed by two ribosomal DNA regions. Mycological Research, 98, 250-256. 
Louw, J. P., \& Korsten, L. (2014). Pathogenic Penicillium spp. on apple and pear. Plant Disease, 98(5), 590-598.

Miller, P. M. (1959). Open calyx tubes as a factor contributing to carpel discoloration and decay of apples. Phytopathology, 49, 520-522.

Morales, H., Marín, S., Rovira, A., Ramos, A. J., \& Sanchis, V. (2007). Patulin accumulation in apples by Penicillium expansum during postharvest stages. Letters of Applied Microbiology, 44(1), 30-35.

Niem, J., Miyara, I., Ettedgui, Y., Reuveni, M., Flaishman, M., \& Pruisky, D. (2007). Core rot development in susceptibility of the seed locule to Alternaria alternata colonization. Phytopathology, 97, 1414-1421.

Pavón, M. A., González, I., Pegels, N., Martín, R., \& García, T. (2010). PCR detection and identification of Alternaria species-groups in processed foods based on the genetic marker Alt a 1. Food Control, 21, 1745-1756.

Peever, T. L., Ibañez, A., Akimitsu, K., \& Timmer, L. W. (2002). Worldwide phylogeography of the citrus brown spot pathogen, Alternaria alternata. Phytopathology, 92, $794-802$.

Peever, T. L., Su, G., Carpenter-Boggs, L., \& Timmer, L. W. (2004). Molecular systematics of citrus-associated Alternaria species. Mycologia, 96, 119-134.

Peever, T. L., Carpenter-Boggs, L., Timmer, L. W., Carris, L. M., \& Bhatia, A. (2005). Citrus black rot is caused by phylogenetically distinct lineages of Alternaria alternata. Phytopathology, 95, 512-518.

Pianzzola, M. J., Moscatelli, M., \& Vero, S. (2004). Characterization of Penicillium isolates associated with blue mold on apple in Uruguay. Plant Disease, 88, $23-28$.

Pitt, J. I., \& Hocking, A. D. (1997). Fungi and food spoilage (2nd ed.). Cambridge: Blackie Academic and Professional, University Press.

Pratella, G. C., \& Mari, M. (1993). Effectiveness of Trichoderma, Gliocladium and Paecilomyces in postharvest fruit protection. Postharvest Biology and Technology, 3, $49-56$.

Pryor, B. M., \& Bigelow, D. M. (2003). Molecular characterization of Embellisia and Nimbya and their relationship to Alternaria, Ulocladium and Stemphylium. Mycologia, 95, 1141-1154.

Pryor, B. M., \& Gilbertson, R. L. (2000). Molecular phylogenetic relationships amongst Alternaria species and related fungi based upon analysis of nuclear ITS and mt SSU rDNA sequences. Mycological Research, 104, 1312-1321.

Pryor, B. M., \& Michailides, T. J. (2002). Morphological, pathogenic, and molecular characterization of Alternaria isolates associated with Alternaria late blight of pistachio. Phytopathology, 92, 406-416.

Rambaut, A. (2002). Sequence alignment editor version 2.0. Oxford: University of Oxford.

Reuveni, M., \& Prusky, D. (2007). Improved control of moldy-core decay (Alternaria alternata) in red delicious apple fruit by mixtures of DMI fungicides and captan. European Journal of Plant Pathology, 118, 349-357.

Reuveni, M., \& Sheglov, D. (2002). Effects of azoxystrobin, difenoconazole, polyoxin B (polar) and trifloxystrobin on germination and growth of Alternaria alternata and decay in red delicious apple fruit. Crop Protection, 21, 951-955.

Reuveni, M., Sheglov, D., \& Cohen, Y. (2003). Control of moldy-core decay in apple fruits of ß-aminobutyric acids and potassium phosphates. Plant Disease, 87, 933936.

Reuveni, M., Sheglov, N., Eshel, D., Prusky, D., \& Ben-Arie, R. (2007). Virulence and the production of endo-1, 4- $\beta$-glucanase by isolates of Alternaria alternata involved in moldy core of apples. Phytopathology, 155, 50-55.

Rharmitt, S., Ha, M., Hajjaj, H., Scordino, F., Giosa, D., Giuffrè, L., Barreca, S., Criseo, G., \& Romeo, O. (2016). Molecular characterization of patulin producing and non-producing Penicillium species in apples from Morocco. International Journal of Food Microbiology, 217, 137-140.

Ronquist, F., \& Huelsenbeck, J. P. (2003). MrBayes 3: Bayesian phylogenetic inference under mixed models. Bioinformatics, $19,1572-1574$.

Samerpitak, K., van der Linde, E., Choi, H.-J., Gerrits van den Ende, A. H. G., Machouart, M., Gueidan, C., \& de Hoog, G. S. (2014). Taxonomy of Ochroconis, genus including opportunistic pathogens on humans and animals. Fungal Diversity, 65, 89-126.

Samson, R. A., Hoekstra, E. S., \& Frisvad, J. C. (2004). Introduction to food and airborne fungi (7th ed.). The Netherlands: Centraalbureau voor Schimmelcultures, Wageningen.

Sanderson, P. G., \& Spotts, R. A. (1995). Postharvest decay of winter pear and apple fruit caused by species of Penicillium. Phytopathology, 85, 103-110.

Seifert, K. A., Samson, R. A., DeWaard, J. R., Houbraken, J., Levesque, C. A., Moncalvo, J.-M., et al. (2007). Prospects for fungus identification using CO1 DNA barcodes, with Penicillium as a test case. Proceedings of the National Academy of Sciences, 104, 3901-3906.

Serdani, M., Crous, P. W., Holz, G., \& Petrini, O. (1998). Endophytic fungi associated with core rot of apples in South Africa, with specific reference to Alternaria species. Sydowia, 50, 257-271.

Serdani, M., Kang, J. C., Andersen, B., \& Crous, P. W. (2002). Characterisation of Alternaria species-groups associated with core rot in South Africa. Mycological Research, 106, 561-569.

Serra, R., Peterson, S., \& Vena, A. (2008). Multilocus sequence identification of Penicillium species in cork bark during plank preparation for the manufacture of stoppers. Research in Microbiology, 159, 178-186.

Shtienberg, D. (2012). Effects of host physiology on the development of core rot, caused by Alternaria alternata, in red delicious apples. Phytopathology, 102, 769-778.

Simmons, E. G. (2007). Alternaria. An Identification Manual. Utrecht: CBS Fungal Biodiversity Centre.

Skouboe, P., Frisvad, J. C., Taylor, J. W., Lauritsen, D., Boysen, M., \& Rossen, L. (1999). Phylogenetic analysis of nucleotide sequences from the ITS region of terverticillate Penicillium species. Mycological Research, 103, 873-881.

Spotts, R. A. (1990). Moldy core and core rot. In A. L. Jones \& H. S. Aldwinckle (Eds.), Compendium of apple and pear diseases (pp. 29-30). St. Paul: APS Press, The American Phytopathological Society. 
Spotts, R. A., Holmes, R. J., \& Washington, W. S. (1988). Factors affecting wet core rot of apples. Australasian Plant Pathology, $17,53-57$.

Swofford, D. L. (2002). PAUP*. Phylogenetic analysis using parsimony (*and other methods). Version (p. 4). Massachusetts: Sinauer Associates, Sunderland.

Taylor, J. (1955). Apple black rot in Georgia and its control. Phytopathology, 45, 392-398.

Theron, D. J., \& Holz, G. (1991). Dry rot of potatoes caused by Gliocladium roseum. Plant Pathology, 40, 302-305.

Thompson, J. D., Higgins, D. G., \& Gibson, T. J. (1994). CLUSTAL W: Improving the sensitivity of progressive multiple sequence alignment through sequence weighting, position-specific gap penalties and weight matrix choice. Nucleic Acids Research, 22, 4673-4680.

Van der Walt, L., Spotts, R. A., Visagie, C. M., Jacobs, K., Smit, F. J., \& McLeod, A. (2010). Penicillium species associated with preharvest wet core rot in South Africa and their pathogenicity on apple. Plant Disease, 94, 666-675.

Van der Walt, L., van der Walt, L., Spotts, R. A., Ueckermann, E. A., Smit, F. J., Jensen, T., \& McLeod, A. (2011). The association of Tarsonemus mites (Acari: Heterostigmata) with different apple developmental stages and apple core rot diseases. International Journal of Acarology, 37(S1), 71-84.

Volk, G. M., Chao, C. T., Norelli, J., Brown, S. K., Fazio, G., Peace, C., McFerson, J., Zhong, G.-Y., \& Bretting, P. (2015). The vulnerability of US apple (Malus) genetic resources. Genetic Resources and Crop Evolution, 62, 765-794.

Wenneker, M., Pham, K. T. K., Lemmers, M. E. C., de Boer, F. A., van der Lans, A. M., van Leeuwen, P. J., Hollinger, T. C., \& Thomma, B. P. H. (2016). First report of Fusarium avenaceum causing wet core rot of 'Elstar' apples in the Netherlands. Plant Disease, 100, 1501.

Woudenberg, J. H., Groenewald, J. Z., Binder, M., \& Crous, P. W. (2013). Alternaria redefined. Studies in Mycology, 75(1), $171-212$.

Woudenberg, J. H. C., et al. (2015). Alternaria section Alternaria: Species, formae speciales or pathotypes? Studies in Mycology, 82, 1-21. AQ8 